\title{
Risk Factors for Depression After a Disaster
}

\author{
Cheryl Person, MD, * Melissa Tracy, MPH, $†$ and Sandro Galea, MD, DrPH†
}

\begin{abstract}
Environmental stressors such as mass disasters may contribute to an increased prevalence of depression within the population affected. We examined the prevalence of probable major depression and risk factors for depression in the 6-month period after the September 11, 2001, attacks on the World Trade Center among New York City (NYC) metropolitan residents. A total of 2700 persons who were representative of the NYC metropolitan area were included in this cross-sectional telephone survey. The prevalence of probable major depression in the 6 months after the attacks was $9.4 \%$. Multivariate logistic regression covariates associated with the likelihood of probable major depression included being directly affected by the attacks, having a perievent panic attack, experiencing multiple life stressors, and having been exposed to previous traumatic events. Mass traumatic event exposure appears to be an independent environmental risk factor for depression in the postdisaster context; specific reactions such as perievent panic attacks may have prognostic value.
\end{abstract}

Key Words: Trauma, mass trauma, depression, perievent panic, stress, disaster.

( $J$ Nerv Ment Dis 2006;194: 659-666)

$A^{1}$ pproximately $6.6 \%$ of persons in the general population have a major depressive episode during the course of a year (Kessler et al., 2003), and the 1-month prevalence of major depressive episodes in the United States has been estimated as 2.2\% (Regier et al., 1993). Unfortunately, depression is as burdensome as it is common. Those who suffer from depression are 27.8 times more likely to have missed work for emotional disability than those who do not (Kouzis and Eaton, 1994). Unipolar depression will be the second leading cause of disability worldwide by 2020 . The only illness projected to be more burdensome is cardiovascular disease (Murray and Lopez, 1997).

Despite the high prevalence and significant morbidity of depression in the population, its etiology remains elusive. There is a twofold to threefold increased risk of depression in

\footnotetext{
*Department of Mental Health, Johns Hopkins Bloomberg School of Public Health, Baltimore, Maryland; and $\dagger$ Center for Social Epidemiology and Population Health, Department of Epidemiology, University of Michigan School of Public Health, Ann Arbor, Michigan.

Send reprint requests to Sandro Galea, MD, DrPH, Department of Epidemiology, University of Michigan School of Public Health, 1214 South University, Room 243, Ann Arbor, MI 48104-2548.

Copyright (C) 2006 by Lippincott Williams \& Wilkins

ISSN: 0022-3018/06/19409-0659

DOI: $10.1097 / 01 . n m d .0000235758 .24586 . b 7$
}

first-degree relatives of those with major depression, and the genetic causes of depression are currently being explored (Sullivan et al., 2000). Heterogeneity in both the expression of the disorder and the risk factors for it has made genetic mapping extraordinarily difficult. There has been some recent progress with the identification of the dopamine receptor gene (DRD4) as one of many potential candidate genes in major depression (Lopez Leon et al., 2005).

Socioenvironmental factors have also been shown to be important in the development of the disorder. Poverty and residing in a disadvantaged neighborhood likely are environmental risk factors for depression (Silver et al., 2002), as are being divorced or separated (Kessler et al., 2005). There is mounting evidence that environmental stressors such as interpersonal trauma are also risk factors for depression (Kendler et al., 2002). For example, depression has been studied in victims of rape and results from the Los Angeles Epidemiologic Catchment Area Study indicate that victims of rape were 2.4 times more likely to suffer from depression than nonassaulted matched controls (Burnam et al., 1988). Similarly, other work has shown that victims of nonsexual assault were $50 \%$ more likely to suffer from symptoms of depression than those who were not assaulted (Driscoll et al., 1995).

Environmental stressors such as mass disasters may contribute to an increased risk of depression within a population, but what the increased risk may be has yet to be elucidated. Reports of depression prevalence rates after disaster vary widely and are likely related to both the timing of the assessment and the type of disaster studied (Rubonis and Bickman, 1991). Bromet and Dew (1995) found significant heterogeneity in the outcome measures employed after disaster. This heterogeneity makes predication of expected rates of depression at the population level, which may be necessary for planning population level mental health response to a disaster, challenging.

By contrast, there are significantly more studies on postdisaster depression within specific subpopulations. In studies conducted after the Three Mile Island nuclear accident, the prevalence of affective disorders was shown to increase in the first month following the accident, particularly in mothers who were living within 5 miles of the plant (Bromet et al., 1982). After a wave of terrorist acts in France, the prevalence of depression among direct victims was $13.3 \%$ years after the event (Abenhaim et al., 1992). North et al. (1999) found that $22.5 \%$ of direct victims of the Oklahoma City Bombing suffered from major depression 6 months after the attack. Many other populations have been studied after disasters including children (Bolton et al., 2000; Durkin et al., 
1993), rescue/recovery workers (McFarlane and Papay, 1992), and members of the armed forces (Fullerton et al., 1999; Ursano et al., 1995).

Despite our growing knowledge about depression after disaster, especially within specific subpopulations, the prevalence of depression within an entire community affected by mass disaster is still largely unknown. Systematic studies of communities after terrorist acts (as well as natural disasters) are difficult to conduct and therefore are relatively rare. Lomeranz et al. (1994) studied depressed mood in the Israeli population before during and after the 1991 SCUD missile attacks and found that depressed mood increased during the SCUD attacks but returned to baseline within 1 month after the attacks. However, the study focused on depressed mood and not depression as a syndrome. One study found that 1 month after the World Trade Center attacks, 9.7\% of the community living closest to the site suffered from probable depression (Galea et al., 2002). In contrast, a Web-based survey found that the prevalence of depression in a nationally representative sample of respondents was within community norms for general psychological distress as measured by the Brief Symptom Inventory 1 to 2 months after the attacks on the World Trade Center (Schlenger et al., 2002).

Studies that have assessed the specific risk factors for depression after mass disaster are also sparse. Armenian et al. (2002) found that geographic location, suffering from significant loss, and female gender were risk factors for depression 2 years after an earthquake in Armenia. This study's findings were limited to long-term assessment of depression and so do not shed light on depression in the short-term aftermath of a disaster.

In this paper, we used data from a representative population-based survey of residents of the New York City (NYC) metropolitan area to assess the prevalence of and risk factors for depression in the first 6 months after the September 11, 2001, attacks on the World Trade Center (WTC).

\section{METHODS}

\section{Sample}

We conducted a cross-sectional survey of NYC metropolitan area residents 6 months after the attacks on the WTC with oversampling of residents of Manhattan south of 110th Street. All persons who were 18 years old or older, had a household telephone, and spoke English, Spanish, Mandarin, or Cantonese were potentially eligible for this study. All surveys were completed between March 25 and June 25, 2002. The institutional review board of the New York Academy of Medicine approved the study protocols. The overall response rate among those eligible for this survey was $63.5 \%$. The calculation of response rates in this study is discussed in more detail elsewhere (Galea et al., 2003). Sampling weights were developed and applied to our data to adjust for oversampling and to correct for potential selection bias related to the number of household telephones as well as number of persons in a household. Demographically, our sample was representative of the population of the NYC metropolitan area according to the 2000 US Census (Census Bot, 2000).

\section{Data Collection}

All fieldwork was conducted by a professional survey firm with experience using telephone surveys to conduct health interviews of disaster survivors, victims of sexual assault, and combat veterans. After obtaining verbal informed consent, the trained interviewers conducted a computer-assisted telephone interview that lasted approximately 35 minutes. Random-digit dialing was used to choose households and, within the household, the adult with the most recent birthday was selected for participation. Interviews were conducted in English, Spanish, Mandarin, or Cantonese using translated and back-translated questionnaires.

Our interviewers asked participants to answer questions related to two distinct time periods: since September 11, 2001, and the last 30 days. Questions that were included in this study are variables that were a priori considered to be potential risk factors for postdisaster psychopathology based on the existing literature. For ease of discussion, we consider answers to questions related to the last 30 days as "current." The survey instrument assessed demographics including age, gender, ethnicity, education, income, and marital status. Social support was also measured using a 5-item modified version of the Medical Outcomes Study social support scale (Sherbourne and Stewart, 1991); this abbreviated scale has a Cronbach $\alpha$ of 0.9 (Ahern et al., 2004). Scores ranged between 4 and 20 and for these analyses we categorized the outcome as low, medium, or high. We assessed the experience of traumatic events before September 11, 2001, including natural disaster, serious accident, and assault with or without a weapon, categorizing the number of events as 0,1 , 2 to 3 , and $\geq 4$. We also assessed life stressors in the 12 months before September 11, 2001, and since September 11, 2001. To measure life stressors, we asked about seven events that a person could have experienced. These included having a mate die, having a close friend die, being seriously injured or ill, getting married, getting divorced, having family or work problems, or having emotional problems. The number of reported life stressors was categorized as 0,1 , or $\geq 2$ for this analysis. We assessed participants' involvement in the attacks. Participants who endorsed any of the following were considered to have been directly affected by the attacks: being in the WTC complex at the time of the attacks, having a friend or relative killed in the attacks, being injured in the attacks, losing possessions, losing property, losing their jobs as a result of the attacks, or being involved in the rescue efforts.

We assessed perievent panic attack using a modified version of the Diagnostic Interview Schedule subscale for panic (Robins et al., 1999). Participants had to endorse at least four of the symptoms listed in the DSM-IV for panic attack within the first few hours after the WTC attacks to have a diagnosis of perievent panic attack.

We used the National Women's Study PTSD module to assess PTSD symptoms since the attacks. In a field trial of the National Women's Study with the Structured Clinical Interview for DSM-IV-TR (SCID), the $\kappa$ was .77 for lifetime PTSD and .71 for current PTSD (Kilpatrick et al., 1998). We assessed probable PTSD that was related to the WTC attacks 
based on the presence of criterion B, C, and D symptoms from the module. Probable PTSD since September 11, 2001, and in the 30 days prior to the interview (current) was assessed. The participants were then required to report at least one re-experiencing symptom specific to the attacks, at least three avoidance symptoms related to the attacks, and two arousal symptoms since the attacks for a diagnosis of probable PTSD related to the attacks. This measure has been used extensively in past studies of the WTC disaster (Boscarino et al., 2004; Galea et al., 2002, 2003).

We used an adapted version of the SCID's major depressive disorder subscale from the nonpatient version (Spitzer et al., 1992) to assess for a major depressive episode. This instrument has been used in several other population studies (Boscarino et al., 2004; Galea et al., 2002; Kilpatrick et al., 1998). Participants had to endorse five or more symptoms listed for major depressive disorder for at least 2 weeks. Cronbach $\alpha$ for the 8 symptoms used in this scale was .79 (Boscarino et al., 2002). We asked about such an episode at two different time points, since September 11, 2001, and within the last 30 days. We have previously compared the results for depression in the past 30 days with those obtained by using the Brief Symptom Inventory-18 (BSI-18) (Zabora et al., 2001) and showed the BSI-18 depression subscale had a sensitivity of $73 \%$ and a specificity of $87 \%$ in detecting depression as classified by our depression instrument (Boscarino et al., 2004). Since we did not assess either manic or psychotic symptoms, we could not further classify the disorder beyond probable major depression.

\section{Statistical Analyses}

We calculated the prevalence of probable major depression since September 11, 2001, and current probable depression. We also assessed the prevalence of PTSD, both since
September 11, 2001, and current, among participants with probable major depression. Two-tailed $\chi^{2}$ tests were used to determine the associations between the covariates of interest and probable major depression since September 11, 2001. Variables that were associated with probable major depression $(p<0.05)$ in bivariate analyses were considered for the final model. Multiple logistic regression was used to determine which covariates were associated with probable major depression since September 11, 2001. We repeated this procedure for current probable major depression. All analyses were carried out using SUDAAN software to account for the complex survey weighting (Research Triangle Institute, Research Triangle Park, North Carolina).

\section{RESULTS}

Of the 2752 participants in the study, 52 were excluded because of missing variables. Demographically, the participants were representative of the NYC metropolitan area population as documented in the 2000 US Census: $53.9 \%$ of our sample were women, $53.2 \%$ were white, and $75.8 \%$ were between the ages of 25 and 64 (Table 1). The weighted period prevalence of probable depression since September 11, 2001, was $9.4 \%$, and the weighted period prevalence of current probable depression was $3.9 \%$. Of the 300 participants with probable depression since September 11, 2001, 24.2\% also had WTC-related PTSD since September 11, 2001. Of the 112 participants with current probable depression, $8.3 \%$ also had current WTC-related PTSD.

Table 2 shows the results of the bivariate analyses. The covariates associated with reporting probable major depression since September 11, 2001, were being directly affected by the attacks $(p<0.0001)$, having a perievent panic attack $(p<0.0001)$, age $(p=0.001)$, marital status $(p=0.001)$, and

TABLE 1. Comparison of Demographic Characteristics of Sample to US Census 2000

\begin{tabular}{|c|c|c|c|c|c|c|c|c|c|c|c|c|}
\hline & \multicolumn{4}{|c|}{$\begin{array}{l}\text { Manhattan, Below 110th Street } \\
\qquad(N=854)\end{array}$} & \multicolumn{4}{|c|}{$\begin{array}{l}\text { New York City } \\
\qquad(N=1570)\end{array}$} & \multicolumn{4}{|c|}{$\begin{array}{l}\text { New York Metropolitan Area } \\
\qquad(N=2752)\end{array}$} \\
\hline & $N$ & $\begin{array}{c}\text { Weighted } \\
\% \text { from } \\
\text { Sample }\end{array}$ & $\begin{array}{c}\text { US } \\
\text { Census } \\
\% \\
\end{array}$ & $\begin{array}{c}p \\
\text { Value }\end{array}$ & $N$ & $\begin{array}{l}\text { Weighted } \\
\% \text { from } \\
\text { Sample }\end{array}$ & $\begin{array}{c}\text { US } \\
\text { Census } \\
\% \\
\end{array}$ & $\begin{array}{c}p \\
\text { Value } \\
\end{array}$ & $N$ & $\begin{array}{l}\text { Weighted } \\
\% \text { from } \\
\text { Sample }\end{array}$ & $\begin{array}{c}\text { US } \\
\text { Census } \\
\% \\
\end{array}$ & $\begin{array}{c}p \\
\text { Value } \\
\end{array}$ \\
\hline Age (in years) & & & & 0.86 & & & & 0.56 & & & & 0.64 \\
\hline $18-24$ & 63 & 7.8 & 10.6 & & 157 & 14.7 & 13.2 & & 261 & 13.7 & 11.7 & \\
\hline $45-54$ & 161 & 17.5 & 16.2 & & 286 & 18.3 & 16.7 & & 521 & 18.9 & 17.7 & \\
\hline $55-64$ & 99 & 11.1 & 11.3 & & 175 & 11.2 & 11.3 & & 333 & 12.2 & 11.8 & \\
\hline $65+$ & 119 & 12.2 & 14.9 & & 190 & 9.2 & 15.5 & & 341 & 10.5 & 16.5 & \\
\hline Gender & & & & 0.31 & & & & 0.67 & & & & 0.87 \\
\hline Male & 410 & 52.2 & 47.2 & & 697 & 44.1 & 46.2 & & 1273 & 46.1 & 46.9 & \\
\hline Female & 444 & 47.8 & 52.8 & & 873 & 55.9 & 53.8 & & 1479 & 53.9 & 53.1 & \\
\hline Asian & 88 & 8.2 & 12.5 & & 118 & 6.3 & 10.1 & & 166 & 5.4 & 7.7 & \\
\hline Hispanic & 162 & 18.6 & 13.7 & & 332 & 28.7 & 24.7 & & 465 & 20.6 & 18.5 & \\
\hline Other & 18 & 1.9 & 2.3 & & 53 & 5.5 & 3.6 & & 91 & 4.2 & 2.6 & \\
\hline
\end{tabular}


TABLE 2. Bivariate Associations Between Depression and Sociodemographic Characteristics and Event Experiences, NYC Metropolitan Area $(N=2700)$

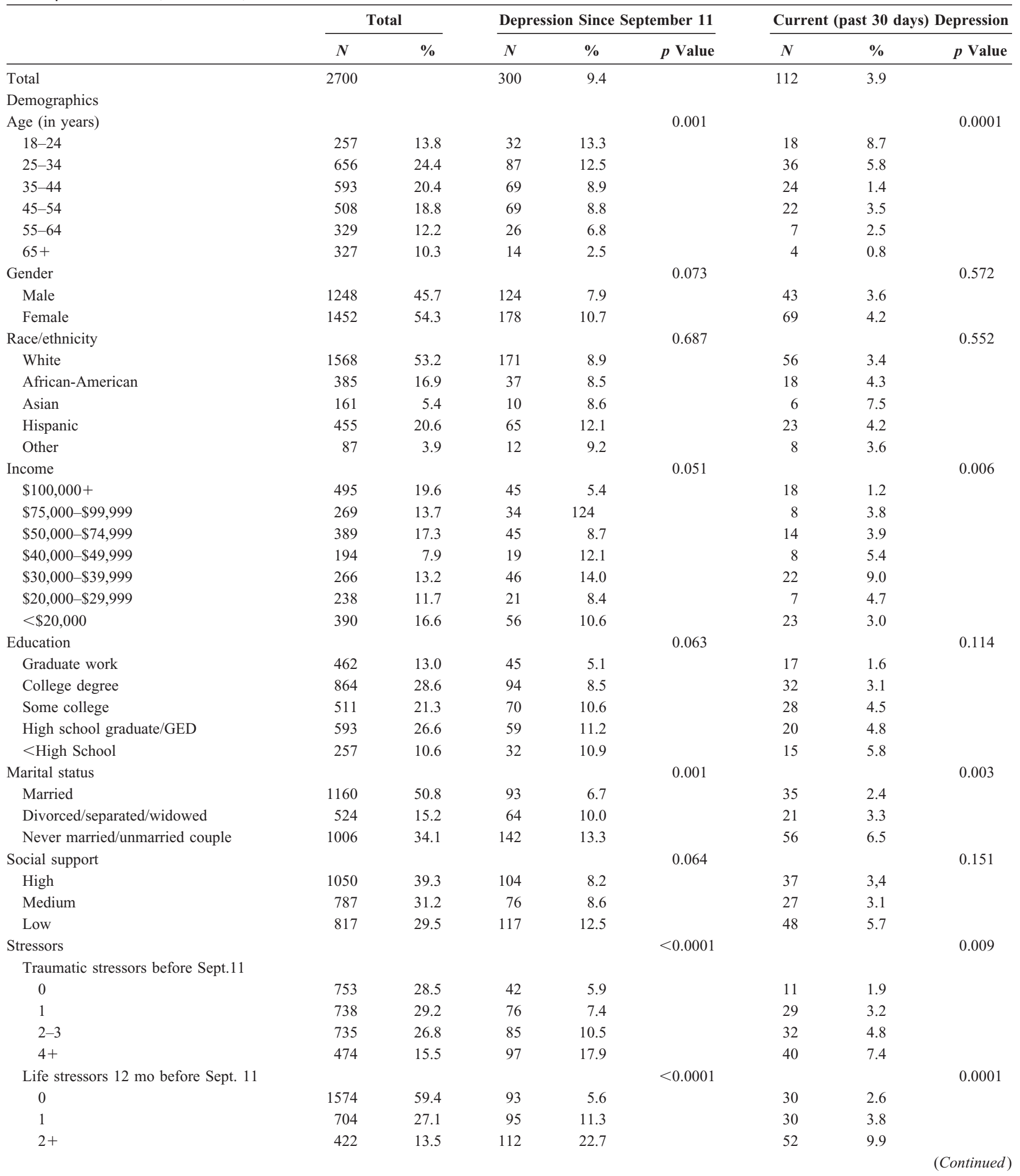


TABLE 2. (Continued)

\begin{tabular}{|c|c|c|c|c|c|c|c|c|}
\hline & \multicolumn{2}{|c|}{ Total } & \multicolumn{3}{|c|}{ Depression Since September 11} & \multicolumn{3}{|c|}{ Current (past 30 days) Depression } \\
\hline Life stressors since Sept. 11 & & & & & $<0.0001$ & & & 0.0003 \\
\hline Yes & 271 & 10.0 & 60 & 19.0 & & 26 & 10.1 & \\
\hline Event experiences & & & & & $<0.0001$ & & & 0.040 \\
\hline \multicolumn{9}{|l|}{ Perievent panic attack } \\
\hline Yes & 388 & 13.6 & 122 & 25.5 & & 34 & 6.4 & \\
\hline Directly affected by attacks ${ }^{\mathrm{a}}$ & & & & & $<0.0001$ & & & 0.032 \\
\hline No & 1902 & 71.8 & 167 & 7.2 & & 63 & 3.2 & \\
\hline Yes & 798 & 28.3 & 133 & 15.1 & & 49 & 5.8 & \\
\hline
\end{tabular}

${ }^{\text {a}}$ Directly affected includes persons who were in the WTC complex during the attacks, were injured during the attacks, lost possessions or property, had a friend or relative killed, lost a job as a result of the attacks, or were involved in the rescue efforts.

all categories of traumatic events and life stressors (all $p$ values $<0.0001)$. The covariates associated with current probable major depression include being directly affected by the attacks $(p=0.032)$, having a perievent panic attack $(p=0.040)$, age $(p=0.0001)$, income $(p=0.006)$, marital status $(p=0.003)$, and all categories of traumatic events and life stressors (all $p$ values $<0.05$ ).

In a multivariate logistic regression model (Table 3), covariates associated with probable major depression since September 11, 2001, were being directly affected by the attacks (odds ratio [OR] = 1.69; confidence interval [CI], $1.11-2.57)$, having a perievent panic attack $(\mathrm{OR}=3.20 ; 95 \%$ CI, 2.06-4.98), experiencing two or more life stressors in the 12 months before September 11, 2001 (OR = 2.86 vs. no stressors; 95\% CI, 1.72-4.75), and experiencing four or more traumatic events before September 11, 2001 (OR $=1.97$ vs. no traumatic events; $95 \% \mathrm{CI}, 1.10-3.54)$. If the participant was single or part of an unmarried couple, the OR of a probable major depression was 1.85 (vs. married; 95\% CI, 1.14-2.98). A protective factor against probable major depression after September 11, 2001, was being 65 years of age or older $(\mathrm{OR}=.30$ vs. $18-24$ years old; $95 \%$ CI, $0.12-0.74)$.

Factors associated with current probable major depression in a multivariate logistic regression model (Table 3) were experiencing two or more life stressors in the 12 months prior to September 11, 2001 (OR $=3.15$ vs. no stressors; 95\% CI, 1.37-7.24), and having life stressors since September 11, 2001 (OR = 2.46 vs. no stressors; 95\% CI, 1.175.18). Being 65 years old or older was again protective against current probable major depression $(\mathrm{OR}=0.11$ vs. 18-24 years old; 95\% CI, 0.02-0.56). Income was also associated with current probable major depression but not in a straightforward way. Those with incomes between $\$ 20,000$ and $\$ 49,999$ had increased risk of current probable major depression compared with those with incomes at either extreme.

\section{DISCUSSION}

In this study, we found that the 6-month period prevalence of probable major depression in the general population was $9.4 \%$ after the September 11,2001 , terrorist attacks. In contrast, previous studies suggest that the expected 6-month period prevalence of depression in nontraumatized populations is $1.5 \%$ to $2.8 \%$ (Horwath et al., 2002). We also found that the prevalence of current past month major depressive episode was $3.9 \%$; this compares to estimates of current major depressive episode in the general population of $2.2 \%$ to $4.9 \%$ documented in other work (Blazer et al., 1994; Regier et al., 1993). Thus, although our findings suggest that the prevalence of probable major depression over the 6-month period after an unprecedented disaster was elevated, the prevalence 6 months after the disaster was within the range we would expect in the general population. This study appears to support the hypothesis that disasters, as environmental stressors, are related to brief but significant elevations in the prevalence of depression in the population. Because of the cross-sectional nature of this study, we are unable to determine causality, and prospective studies are necessary to confirm this observation.

We also found that persons who were directly affected by a terrorist attack were more likely to have probable major depression in the aftermath of the disaster. This is similar to the findings of Shore et al. (1986), who found that greater exposure to a natural disaster led to higher levels of depression. Several other studies have found some relation between disaster exposure and depression. Maes et al. (2000) found that the best predictor of subsequent depression after either motor vehicle accidents or fires was physical injury. Another study found that sustaining severe property damage (but not severe physical threat) after a hurricane was the best predictor of subsequent negative psychological sequelae (David et al., 1996). In the aftermath of a terrorist attack, we also found a relation between traumatic exposure and subsequent depression.

Having a perievent panic attack was a robust predictor of probable major depression in the postdisaster period. This is consistent with several studies that indicate an increased risk of major depressive disorder in those who have panic attacks (Andrade et al., 1996; Goodwin, 2002). Goodwin et 
TABLE 3. Multivariable Models Predicting Depression, NYC Metropolitan Area $(N=2700)$

\begin{tabular}{|c|c|c|c|c|c|c|c|c|}
\hline \multirow[b]{2}{*}{ Demographics } & \multicolumn{4}{|c|}{ Depression Since September 11} & \multicolumn{4}{|c|}{ Current (past 30 d) Depression } \\
\hline & OR & $95 \% \mathrm{CI}$ & OR & $95 \%$ CI & OR & $95 \% \mathrm{CI}$ & OR & $95 \%$ CI \\
\hline \multicolumn{9}{|l|}{ Age (in years) } \\
\hline $18-24$ & 1.00 & & 1.00 & & 1.00 & & 1.00 & \\
\hline $25-34$ & 0.93 & $0.53-1.63$ & 1.02 & $0.56-1.87$ & 0.65 & $0.31-1.34$ & 0.53 & $0.24-1.14$ \\
\hline $55-64$ & 0.48 & $0.23-0.99$ & 0.63 & $0.28-1.42$ & 0.27 & $0.08-0.92$ & 0.26 & $0.07-1.00$ \\
\hline $65+$ & 0.17 & $0.07-0.41$ & 0.30 & $0.12-0.74$ & 0.09 & $0.02-0.33$ & 0.11 & $0.02-0.56$ \\
\hline \multicolumn{9}{|l|}{ Income } \\
\hline$\$ 100,000+$ & & & & & 1.00 & & 1.00 & \\
\hline$\$ 75,000-\$ 99,999$ & & & & & 3.38 & $0.98-11.63$ & 3.19 & $0.94-10.87$ \\
\hline$\$ 50,000-\$ 74,999$ & & & & & 3.46 & $1.08-11.03$ & 3.07 & $0.93-10.07$ \\
\hline$<20,000$ & & & & & 2.62 & $0.86-7.96$ & 1.92 & $0.58-6.32$ \\
\hline \multicolumn{9}{|l|}{ Marital status } \\
\hline Married & 1.00 & & 1.00 & & 1.00 & & 1.00 & \\
\hline Divorced/separated widowed & 1.54 & $0.95-2.47$ & 1.48 & $0.88-2.51$ & 1.39 & $0.60-3.20$ & 1.08 & $0.38-3.07$ \\
\hline Never married/unmarried couple & 2.14 & $1.44-3.18$ & 1.85 & $1.14-2.98$ & 2.84 & $1.52-5.31$ & 1.21 & $0.63-2.34$ \\
\hline \multicolumn{9}{|l|}{ Stressors } \\
\hline \multicolumn{9}{|l|}{ Traumatic stressors before Sept.11 } \\
\hline 0 & 1.00 & & 1.00 & & 1.00 & & 1.00 & \\
\hline 1 & 1.26 & $0.72-2.20$ & 1.26 & $0.72-2.22$ & 1.69 & $0.67-4.28$ & 1.10 & $0.39-3.06$ \\
\hline $2-3$ & 1.85 & $1.06-3.24$ & 1.38 & $0.76-2.49$ & 2.63 & $1.02-6.74$ & 1.16 & $0.43-3.14$ \\
\hline $4+$ & 3.46 & $1.98-6.03$ & 1.97 & $1.10-3.54$ & 4.15 & $1.66-10.33$ & 1.74 & $0.61-4.96$ \\
\hline \multicolumn{9}{|l|}{ Perievent panic attack } \\
\hline No & 1.00 & & 1.00 & & 1.00 & & 1.00 & \\
\hline Yes & 4.63 & $3.13-6.84$ & 3.20 & $2.06-4.98$ & 1.88 & $1.03-3.44$ & 0.87 & $0.37-2.02$ \\
\hline \multicolumn{9}{|l|}{ Directly affected by attacks ${ }^{\mathrm{a}}$} \\
\hline No & 1.00 & & 1.00 & & 1.00 & & 1.00 & \\
\hline Yes & 2.28 & $1.59-3.29$ & 1.69 & $1.11-2.57$ & 1.89 & $1.06-3.39$ & 1.38 & $0.70-2.71$ \\
\hline
\end{tabular}

${ }^{a}$ Directly affected includes persons who were in the WTC complex during the attacks, were injured during the attacks, lost possessions or property, had a friend or relative killed, lost a job as a result of the attacks, or were involved in the rescue efforts.

al. (2004) have also shown that panic attacks, even without a diagnosis of panic disorder, seem to predate major depression in adolescents and young adults. In assessing incident major depression at follow-up, those with baseline panic attacks were more likely to develop new-onset major depression than those without (OR = 2.8; CI, 1.5-5.1; Goodwin et al., 2004). Boscarino et al. (2004) have preliminarily shown a bivariate relationship between perievent panic attacks and past year depression after the attacks on the WTC. To the best of our knowledge, this is only the second time the relationship between perievent panic attacks and depression has been reported in the postdisaster context, and these data are consistent with literature describing this phenomenon in nontraumatized populations. Further studies are warranted to understand the relationship between perievent panic attacks and subsequent depression.

Being directly affected by the disaster or having a perievent panic attack was not related to current (last 30 days) probable major depression in multivariate analyses, although both conditions were significantly associated with current 
depression in bivariate analysis. However, our sample of persons reporting current major depression was small, and a large sample size may show that these variables are important determinants of current depression in the population. Alternatively, a stressful event may confer an at-risk period, which lasts less than 6 months, decreasing the contribution of acute stressful events to later-onset depression. A recent literature review showed that the effect of acute stressors on depression dissipates with time (Tennant, 2002). Thus, the effect of being directly affected by the attacks or experiencing a perievent panic attack on current depression may not have been as important as it was for the initial postdisaster period. It is important for future studies to attempt prospectively to replicate this finding, which may provide further insight about a period of elevated depression risk after disasters.

This study confirms reports from other work about the role of key sociodemographic determinants of depression. Being either single or part of an unmarried couple increased the risk of probable major depression in the 6-month period after the September 11, 2001, attacks. This is consistent with previous studies that have documented marital status as a risk factor for subsequent depression after disasters (Fullerton et al., 1999; Ursano et al., 1995). Stressors either 1 year before September 11, 2001, or stressors since September 11, 2001, were also robust predictors of probable major depression in the aftermath of the attacks, similar to other studies that have found that life stressors are risk factors for major depression (Kendler et al., 1999; Surtees et al., 1986). Our study is congruent with previous work that shows elderly age is protective for both current probable major depression as well as probable major depression since September 11, 2001 (Regier et al., 1993; Wilhelm et al., 2003).

Gender was not a significant predictor of probable depression in the period of study. Women have been shown to have elevated rates of major depression in many other epidemiological studies (Kessler et al., 1993; Regier et al., 1993). However, some studies that have assessed depression after disaster have not found a gender difference after controlling for level of perceived control and self-esteem (Galea et al., 2002; Norris et al., 1999). Other risk factors in the postdisaster environment may be more important determinants of depression than gender.

In this analysis, only $24.4 \%$ of persons with probable major depression had WTC-related PTSD, and only $8.3 \%$ of persons with current (past 30 days) probable major depression had WTC-related PTSD. Depression is an important and understudied illness in the postdisaster context. One study found that in the acute aftermath of trauma, there was a separate construct representing depression in the absence of PTSD (O'Donnell et al., 2004). In addition, Shalev et al. (1998) found that PTSD and major depression are independent sequelae of traumatic events, although they interact to increase both distress and dysfunction. To assess risk factors for depression after disaster more clearly, we felt it was necessary to exclude PTSD from our analysis. It is clear that postdisaster psychopathology includes multiple psychiatric disorders such as depression, substance use disorders, and a range of anxiety disorders, and a clearer understanding of psychopa- thology will ultimately need to take all of these illnesses as well as their complex interactions into consideration.

These results must be interpreted with caution. We did not assess for major depressive disorder. We did not measure either manic or psychotic symptoms; therefore, we were able to assess for probable major depressive episode with certainty, but this does not preclude a diagnosis of bipolar affective disorder. Also, similar to several other studies on postdisaster mental health (Norris et al., 1999; Thiel de Bocanegra and Brickman, 2004), we did not assess lifetime history of major depressive disorder, which is a known risk factor for subsequent episodes. We used lay interviewers and abbreviated measures of depressive symptoms, which were not validated with clinician-administered interviews.

\section{CONCLUSION}

This study showed that the prevalence of probable major depression was greater than expected shortly after the attacks on the WTC and returned to probable baseline rates within 6 months. Exposure to a mass traumatic event then appears to be an independent environmental risk factor for depression in the postdisaster context. We also found that having a perievent panic attack was a robust risk factor for subsequent probable major depression. Perievent panic attacks are rarely measured in the posttrauma context, and this suggests that future studies should both measure and determine the prognostic role of perievent panic attacks.

\section{REFERENCES}

Abenhaim L, Dab W, Salmi LR (1992) Study of civilian victims of terrorist attacks (France 1982-1987). J Clin Epidemiol. 45:103-109.

Ahern J, Galea S, Fernandez WG, Koci B, Waldman R, Vlahov D (2004) Gender, social support and posttraumatic stress in postwar Kosovo. J Nerv Ment Dis. 192:762-770.

Andrade L, Eaton WW, Chilcoat HD (1996) Lifetime co-morbidity of panic attacks and major depression in a population-based study: Age of onset. Psychol Med. 26:991-996.

Armenian HK, Morikawa M, Melkonian AK, Hovanesian A, Akiskal K, Akiskal HS (2002) Risk factors for depression in the survivors of the 1988 earthquake in Armenia. J Urban Health. 79:373-382.

Blazer DG, Kessler RC, McGonagle KA, Swartz MS (1994) The prevalence and distribution of major depression in a national community sample: The National Comorbidity Survey. Am J Psychiatry. 151:979-986.

Bolton D, O'Ryan D, Udwin O, Boyle S, Yule W (2000) The long-term psychological effects of a disaster experienced in adolescence: II: General pyschopathology. J Child Psychol Psychiatry. 41:513-523.

Boscarino JA, Adams RE, Figley CR (2004) Mental health service use 1-year after the World Trade Center disaster: Implications for mental health care. Gen Hosp Psychiatry. 26:346-358.

Boscarino JA, Galea S, Ahern J, Resnick H, Vlahov D (2002) Utilization of mental health services following the September 11th terrorist attacks in Manhattan, New York City. Int J Emerg Ment Health. 4:143-155.

Bromet E, Dew MA (1995) Review of psychiatric epidemiologic research on disasters. Epidemiol Rev. 17:113-119.

Bromet EJ, Parkinson DK, Schulberg HC, Dunn LO, Gondek PC (1982) Mental health of residents near the Three Mile Island reactor: A comparative study of selected groups. J Prev Psychiatry. 1:225-276.

Burnam MA, Stein JA, Golding JM, Siegel JM, Sorenson SB, Forsythe AB, Telles CA (1988) Sexual assault and mental disorders in a community population. J Consult Clin Psychol. 56:843-850.

Census Bot (2000) US Department of Commerce (Ed), Census Summary Tape, File (STF3A).

David D, Mellman TA, Mendoza LM, Kulick-Bell R, Ironson G, Schneiderman N (1996) Psychiatric morbidity following Hurricane Andrew. J Trauma Stress. 9:607-612. 
Driscoll RJ, Worthington KA, Hurrell JJ (1995) Workplace assault: An emerging job stressor. Consult Psychol J. 47:163-170.

Durkin MS, Khan N, Davidson LL, Zaman SS, Stein ZA (1993) The effects of a natural disaster on child behavior: Evidence for posttraumatic stress. Am J Public Health. 83:1549-1553.

Fullerton CS, Ursano RJ, Kao TC, Bharitya VR (1999) Disaster-related bereavement: acute symptoms and subsequent depression. Aviat Space Environ Med. 70:902-909.

Galea S, Ahern J, Resnick H, Kilpatrick D, Bucuvalas M, Gold J, Vlahov D (2002) Psychological sequelae of the September 11 terrorist attacks in New York City. N Engl J Med. 346:982-987.

Galea S, Vlahov D, Resnick H, Ahern J, Susser E, Gold J, Bucuvalas M, Kilpatrick D (2003) Trends of probable post-traumatic stress disorder in New York City after the September 11 terrorist attacks. Am J Epidemiol. 158:514-524.

Goodwin RD (2002) Anxiety disorders and the onset of depression among adults in the community. Psychol Med. 32:1121-1124.

Goodwin RD, Lieb R, Hoefler M, Pfister H, Bittner A, Beesdo K, Wittchen HU (2004) Panic attack as a risk factor for severe psychopathology. Am J Psychiatry. 161:2207-2214.

Horwath E, Cohen RS, Weissman MM (2002) Epidemiology of depressive and anxiety disorders. In MT Tsuang, M Tohen (Eds), Textbook in Psychiatric Epidemiology (pp 389-426). New York: Wileg-Liss.

Kendler KS, Gardner CO, Prescott CA (2002) Toward a comprehensive developmental model for major depression in women. Am J Psychiatry. 159:1133-1145.

Kendler KS, Karkowski LM, Prescott CA (1999) Causal relationship between stressful life events and the onset of major depression. Am J Psychiatry. 156:837-841.

Kessler RC, Berglund P, Demler O, Jin R, Koretz D, Merikangas KR, Rush AJ, Walters EE, Wang PS (2003) The epidemiology of major depressive disorder: Results from the National Comorbidity Survey Replication (NCS-R). JAMA. 289:3095-3105.

Kessler RC, Berglund P, Demler O, Jin R, Walters EE (2005) Lifetime prevalence and age-of-onset distributions of DSM-IV disorders in the National Comorbidity Survey Replication. Arch Gen Psychiatry. 62:593602.

Kessler RC, McGonagle KA, Swartz M, Blazer DG, Nelson CB (1993) Sex and depression in the National Comorbidity Survey, I: Lifetime prevalence, chronicity and recurrence. J Affect Disord. 29:85-96.

Kilpatrick D, Resnick H, Freedy J, Pelcovitz D, Resnick P, Roth S, van der Kolk B (1998) The posttraumatic stress disorder field trial: Evaluation of the PTSD construct-criteria A through E. In TA Widiger, AJ Frances, HA Pincus, et al. (Eds), DSM-IV Sourcebook (Vol 4, pp 803-844). Washington, DC: American Psychiatric Association Press.

Kouzis AC, Eaton WW (1994) Emotional disability days: Prevalence and predictors. Am J Public Health. 84:1304-1307.

Lomeranz J, Hobfoll SE, Johnson R, Eyal N, Zemach M (1994) A nation's resonse to attack: Israelis' depressive reactions to the Gulf War. $J$ Trauma Stress. 7:59-73.

Lopez Leon S, Croes EA, Sayed-Tabatabaei FA, Claes S, Van Broeckhoven C, van Duijn CM (2005) The dopamine D4 receptor gene 48-base-pairrepeat polymorphism and mood disorders: A meta-analysis. Biol Psychiatry. 57:999-1003.

Maes M, Mylle J, Delmeire L, Altamura C (2000) Psychiatric morbidity and comorbidity following accidental man-made traumatic events: Incidence and risk factors. Eur Arch Psychiatry Clin Neurosci. 250:156-162.

McFarlane AC, Papay P (1992) Multiple diagnoses in posttraumatic stress disorder in the victims of a natural disaster. J Nerv Ment Dis. 180:498504.
Murray CJ, Lopez AD (1997) Alternative projections of mortality and disability by cause 1990-2020: Global Burden of Disease Study. Lancet. 349:1498-1504.

Norris FH, Perilla JL, Riad JK, Kaniasty K, Lavizzo EA (1999) Stability and change in stress, resources and psychological distress following natural disaster: Findings from Hurricane Andrew. Anxiety Stress Coping. 12: 363-396.

North CS, Nixon SJ, Shariat S, Mallonee S, McMillen JC, Spitznagel EL, Smith EM (1999) Psychiatric disorders among survivors of the Oklahoma City bombing. JAMA. 282:755-762.

O'Donnell ML, Creamer M, Pattison P (2004) Posttraumatic stress disorder and depression following trauma: Understanding comorbidity. Am J Psychiatry. 161(8):1390-1396.

Regier DA, Farmer ME, Rae DS, Myers JK, Kramer M, Robins LN, George LK, Karno M, Locke BZ (1993) One-month prevalence of mental disorders in the United States and sociodemographic characteristics: The Epidemiologic Catchment Area study. Acta Psychiatr Scand. 88:35-47.

Robins LN, Cottler LB, Bucholz KK, Compton WM, North CS, Rourke KM (1999) Diagnostic Interview Schedule for DSM-IV. St. Louis (MO): Washington University School of Medicine.

Rubonis AV, Bickman L (1991) Psychological impairment in the wake of disaster: The disaster-psychopathology relationship. Psychol Bull. 109: 384-399.

Schlenger WE, Caddell JM, Ebert L, Jordan BK, Rourke KM, Wilson D, Thalji L, Dennis JM, Fairbank JA, Kulka RA (2002) Psychological reactions to terrorist attacks: Findings from the National Study of Americans' Reactions to September 11. JAMA. 288:581-588.

Shalev AY, Freedman S, Peri T, Brandes D, Sahar T, Orr SP, Pitman RK (1998) Prospective study of posttraumatic stress disorder and depression following trauma. Am J Psychiatry. 155(S):630-637.

Sherbourne CD, Stewart AL (1991) The MOS social support survey. Soc Sci Med. 32:705-714.

Shore JH, Tatum EL, Vollmer WM (1986) Psychiatric reactions to disaster: The Mount St. Helens experience. Am J Psychiatry. 143:590-595.

Silver E, Mulvey EP, Swanson JW (2002) Neighborhood structural characteristics and mental disorder: Faris and Dunham revisited. Soc Sci Med. 55:1457-1470.

Spitzer RL, Williams JB, Gibbon M, First MB (1992) The Structured Clinical Interview for DSM-III-R (SCID), I: History, rationale and description. Arch Gen Psychiatry. 49:624-629.

Sullivan PF, Neale MC, Kendler KS (2000) Genetic epidemiology of major depression: Review and meta-analysis. Am J Psychiatry. 157:1552-1562.

Surtees PG, Miller PM, Ingham JG, Kreitman NB, Rennie D, Sashidharan SP (1986) Life events and the onset of affective disorder: A longitudinal general population study. $J$ Affect Disord. 10:37-50.

Tennant C (2002) Life events, stress and depression: A review of recent findings. Aust N Z J Psychiatry. 36:173-182.

Thiel de Bocanegra H, Brickman E (2004) Mental health impact of the World Trade Center attacks on displaced Chinese workers. J Trauma Stress. 17:55-62.

Ursano RJ, Fullerton CS, Kao TC, Bhartiya VR (1995) Longitudinal assessment of posttraumatic stress disorder and depression after exposure to traumatic death. $J$ Nerv Ment Dis. 183:36-42.

Wilhelm K, Mitchell P, Slade T, Brownhill S, Andrews G (2003) Prevalence and correlates of DSM-IV major depression in an Australian national survey. J Affect Disord. 75:155-162.

Zabora J, BrintzenhofeSzoc K, Jacobsen P, Curbow B, Piantadosi S, Hooker C, Owens A, Derogatis L (2001) A new psychosocial screening instrument for use with cancer patients. Psychosomatics. 42:241-246. 